\title{
Investigating the role of culture conditions on hypertrophic differentiation in human cartilage endplate cells
}

DOI:

10.1002/jor.24692

\section{Document Version}

Accepted author manuscript

Link to publication record in Manchester Research Explorer

\section{Citation for published version (APA):}

Lakstins, K., Yeater, T., Arnold, L., Khan, S., Hoyland, J., \& Purmessur, D. (2020). Investigating the role of culture conditions on hypertrophic differentiation in human cartilage endplate cells. Journal of orthopaedic research : official publication of the Orthopaedic Research Society. https://doi.org/10.1002/jor.24692

\section{Published in:}

Journal of orthopaedic research : official publication of the Orthopaedic Research Society

\section{Citing this paper}

Please note that where the full-text provided on Manchester Research Explorer is the Author Accepted Manuscript or Proof version this may differ from the final Published version. If citing, it is advised that you check and use the publisher's definitive version.

\section{General rights}

Copyright and moral rights for the publications made accessible in the Research Explorer are retained by the authors and/or other copyright owners and it is a condition of accessing publications that users recognise and abide by the legal requirements associated with these rights.

\section{Takedown policy}

If you believe that this document breaches copyright please refer to the University of Manchester's Takedown Procedures [http://man.ac.uk/04Y6Bo] or contact uml.scholarlycommunications@manchester.ac.uk providing relevant details, so we can investigate your claim.

\section{OPEN ACCESS}


Journal of Orthopaedic Research

WILEY

\section{Investigating the role of culture conditions on hypertrophic differentiation in human cartilage endplate cells}

\begin{tabular}{|r|l|}
\hline Journal: & Journal of Orthopaedic Research \\
\hline Manuscript ID & JOR-19-0826.R1 \\
\hline Wiley - Manuscript type: & Research Article (Member) \\
\hline Date Submitted by the & 17-Feb-2020 \\
\hline Complete List of Authors: & $\begin{array}{r}\text { Lakstins, Katie; The Ohio State University, Biomedical Engineering } \\
\text { Yeater, Taylor; The Ohio State University, Biomedical Engineering } \\
\text { Arnold, Lauren; The Ohio State University, Biomedical Engineering } \\
\text { Khan, Safdar N.; The Ohio State University, Orthopaedics } \\
\text { Hoyland, Judith } \\
\text { Purmessur, Devina; The Ohio State University, Biomedical Engineering }\end{array}$ \\
\hline Keywords: & $\begin{array}{l}\text { Cartilage, Endochondral Ossification, Intervertebral disc, Low Back Pain, } \\
\text { Spine }\end{array}$ \\
\hline Areas of Expertise: & $\begin{array}{l}\text { cartilage endplate, hypertrophic differentiation, low back pain, } \\
\text { calcification, intervertebral disc }\end{array}$ \\
\hline &
\end{tabular}

\section{SCHOLARONE ${ }^{m}$ \\ Manuscripts}


1 Title: Investigating the role of culture conditions on hypertrophic differentiation in human

2 cartilage endplate cells

3 Authors: Katherine Lakstins ${ }^{1}$, Taylor Yeater ${ }^{1}$, Lauren Arnold ${ }^{1}$, Safdar Khan ${ }^{2}$, Judith A

4 Hoyland $^{3,4}$, Devina Purmessur ${ }^{1,2}$

5 Affiliations: ${ }^{1}$ Department of Biomedical Engineering, The Ohio State University, Columbus,

6 OH, USA. ${ }^{2}$ Department of Orthopedics, The Ohio State University, Columbus, OH, USA.

$7 \quad{ }^{3}$ Division of Cell Matrix Biology and Regenerative Medicine, The University of Manchester,

8 Manchester, UK. ${ }^{4}$ NIHR Manchester Biomedical Research Centre, Central Manchester

9 Foundation Trust, Manchester Academic Health Science Centre, Manchester University,

10 Manchester, UK

11 Corresponding author: Devina Purmessur, Dorothy Davis Heart and Lung Research Institute,

12 Room 012L, 473 W 12th Avenue Columbus, OH 43210,614-292-2731, walter.368@,osu.edu

13 Running Title: Hypertrophic differentiation of endplate cells

14 Author contributions:

15 Key: [1] substantial contributions to research design, or the acquisition, analysis or interpretation

16 of data; [2] drafting the paper or revising it critically; [3] approval of the submitted and final

17 version

18 Katherine Lakstins [1][2][3], Taylor Yeater [1][3] Lauren Arnold [1][3], Safdar Khan [1][3],

19 Judith Hoyland [1][3], Devina Purmessur [1][2][3]

20 All authors listed have read and approved the final submitted manuscript. 
21 Abstract:

Cartilage endplate degeneration/calcification has been linked to the onset and progression of intervertebral disc degeneration and there is a critical need to understand mechanisms, such as hypertrophic differentiation, of cartilage endplate degeneration/calcification to inform treatment strategies for discogenic back pain. In vitro cell culture conditions capable of inducing hypertrophic differentiation are used to study pathophysiological mechanisms in articular chondrocytes, but culture conditions capable of inducing a hypertrophic cartilage endplate cell phenotype have yet to be explored. The goal of this study was to investigate the role of culture conditions capable of inducing hypertrophic differentiation in articular chondrocytes on hypertrophic differentiation in human cartilage endplate cells. Isolated human cartilage endplate cells were cultured as pellets for 21 days at either $5 \% \mathrm{O}_{2}$ (physiologic for cartilage) or $20.7 \% \mathrm{O}_{2}$ (hyperoxic) and treated with 10\% fetal bovine serum or Wnt agonist, two stimuli used to induce hypertrophic differentiation in articular chondrocytes. Cartilage endplate cells did not exhibit a hypertrophic cell morphology in response to fetal bovine serum or Wnt agonist but did display other hallmarks of chondrocyte hypertrophy and degeneration such as hypertrophic gene and protein expression, and a decrease in healthy proteoglycans and an increase in fibrous collagen accumulation. These findings demonstrate that cartilage endplate cells take on a degenerative phenotype in response to hypertrophic stimuli in vitro, but do not undergo classical changes in morphology associated with hypertrophic differentiation regardless of oxygen levels, highlighting potential differences in the response of cartilage endplate cells versus articular chondrocytes to the same stimuli.

Key Words: cartilage endplate, hypertrophic differentiation, calcification, intervertebral disc, low back pain 


\section{Introduction:}

Low back pain (LBP) has remained one of the top three leading causes of non-fatal health

46

47 generation are poorly understood ${ }^{4}$.

IVDs are the main joints of the spinal column and are composed of the nucleus pulposus (NP) and annulus fibrosus (AF). The cartilage endplate (CEP) is a thin layer of cartilage between the IVD and the vertebral body ${ }^{5}$. The CEPs distribute intradiscal pressures and prevent bulging of the NP into the adjacent vertebral bodies, and function as a gateway for nutrients and metabolites to enter and exit the avascular, aneural IVD ${ }^{6}$. With disease, the CEPs undergo structural and biochemical alterations including thinning, loss of water, decrease in proteoglycan content and calcification ${ }^{7,8}$. Changes in CEP biochemistry can decrease diffusivity and NP cell viability ${ }^{9}$ and CEP degeneration/calcification is implicated in the onset and progression of disc degeneration ${ }^{6}$. Recent studies have demonstrated alterations in CEP quality may associate with structural damage ${ }^{10}$, which appears to be an initiator of vertebral bone marrow lesions ${ }^{11}$. These vertebral bone marrow lesions and CEP defects are more prevalent in cohorts of patients with chronic LBP ${ }^{12,13}$.

Although pathological changes to the CEP have been implicated in the initiation and progression of IVD degeneration and LBP, few treatment strategies consider therapeutically targeting the $\mathrm{CEP}^{14}$. Therefore, there has been increased focus on mechanisms associated with CEP degeneration and identification of potential therapeutic targets. For example, endochondral ossification, the mechanism by which cartilage differentiates into bone during development, has 
67 been identified as a potential mechanism for CEP calcification. Ectopic calcifications in the human CEP are associated with AGE methylglyoxal-hydroimidazolone-1 and osteogenic markers collagen-X (COLX) and osteopontin. Bovine CEP cells cultured with AGEs

70 demonstrated an increase in ectopic calcifications and this effect was mitigated by inhibition of

71 RAGE (AGE receptor) supporting a role for AGE/RAGE in CEP calcification via endochondral

72 ossification ${ }^{15}$. Another study has shown that ovariectomized mice have osteoporotic vertebrae,

73 degeneration of the IVD and features of endochondral ossification in the CEPs, further

74 implicating endochondral ossification as a potential mechanism by which degeneration is

75 induced in the $\mathrm{CEP}^{16}$. Additionally, calcified CEP tissue isolated from rats with IVD

76 degeneration demonstrated high levels of leptin expression. Leptin increased expression of

77 hypertrophy markers osteocalcin and runt-related transcription factor 2 via the ERK1/2 signaling

78 pathways in a dose and time dependent manner in CEP cells in vitro ${ }^{17}$. Furthermore,

79 intraperitoneal injection of Ligustrazine (a natural compound isolated from Chinese herbal medicine Ligusticum wallichii) into rats with IVD degeneration attenuated CEP hypertrophy via

81 suppression of TGF- $\beta^{18}$. These studies highlight a potential role for endochondral ossification,

82 specifically hypertrophic differentiation, in CEP calcification/degeneration.

In vitro cell culture conditions capable of inducing hypertrophic differentiation are used

84 to study pathophysiological mechanisms in articular chondrocytes, however, culture conditions capable of inducing or recapitulating CEP cell hypertrophy in vitro have yet to be identified. Our

86 aim was to investigate the role of culture conditions capable of inducing hypertrophic

87 differentiation in articular chondrocytes on hypertrophic differentiation in human cartilage endplate cells. Both Wnt agonist and 10\% fetal bovine serum (FBS) have been used to induce 89 hypertrophic differentiation in articular chondrocytes in vitro ${ }^{19-23}$. As such, we explored the 
90 effects of Wnt agonist and 10\% FBS on CEP cells. Developing an in vitro cell culture model of

91 hypertrophy using physiologically relevant osteogenic signaling pathways, such as the Wnt/ $\beta$ -

92 catenin pathway will give researchers the ability to control and explore aspects of CEP cell

93 hypertrophy in vitro. In addition, both physiologic $\left(5 \% \mathrm{O}_{2}\right)$ oxygen levels experienced by

94 cartilage and hyperoxic $\left(20.7 \% \mathrm{O}_{2}\right)$ oxygen levels were evaluated. Oxygen tension has been

95 shown to play a role in regulation of IVD cell metabolism, gene expression and matrix

96 production ${ }^{24-27}$. Lower oxygen levels experienced by cartilage and disc can inhibit hypertrophic

97 differentiation in chondrocytes in vitro ${ }^{28}$. Decreases in expression of hypoxia-inducible factor-1 $\alpha$

98 in the degenerated CEP suggests a less hypoxic microenvironment ${ }^{29}$ likely due to

99

100

101

102

103

104

105

106

107

108

109

110

111

112

neovascularization of the CEP with disease and these processes may augment hypertrophic differentiation of the CEP.

We hypothesized Wnt agonist and 10\% FBS media would induce a degenerate phenotype via hypertrophic differentiation compared with Chondrogenic and Basal control media. Furthermore, we hypothesized that culturing CEP cells in 5\% $\mathrm{O}_{2}$ would limit hypertrophic differentiation induced by $10 \%$ FBS and Wnt agonist. Consequently, culturing CEP cells in 10\% FBS or Wnt agonist media in $20.7 \%$ oxygen would enhance hypertrophic differentiation in CEP cells. The mechanisms of CEP degeneration/calcification are underexplored and identification of culture conditions capable of inducing hypertrophic differentiation in vitro could significantly contribute to elucidating the role of the CEP in IVD degeneration and LBP.

\section{Methods:}

\section{Primary cell isolation and expansion}

CEP cells were isolated from $n=11$ human cadaveric lumbar spines (Table 1) within 36 hours of death (Cooperative Human Tissue Network, Columbus, Ohio). Individual IVDs were isolated from 
113 each spine. Macroscopic images of IVDs were taken, blinded and graded using the Thompson 114 grading scale ${ }^{30}$ by two individual expert spine researchers. Images of IVDs for CEP6 and CEP8 115 were not available and therefore Thompson grades are unavailable. Vertebral bodies were scraped 116 to remove any remaining NP or AF tissue. The CEP tissue was carefully dissected from the 117 vertebral bodies to ensure only shiny translucent hyaline cartilage was removed and cells were 118 isolated using 0.2\% protease (from Streptomyces griseus - Type XIV: P5147, Sigma-Aldrich, MO, 119 USA) for 1 hour at $37^{\circ} \mathrm{C}$, followed by digestion with $0.012 \%$ collagenase-II (from Clostridium 120 Histolyticum - 17101015, Thermo Fisher Scientific, MA, USA) for 12 hours at $37^{\circ} \mathrm{C}^{31}$. Cells were 121 expanded in disc cell media (Dulbecco's Modified Eagle Medium (DMEM, 4.5g/L glucose 122 11995115, Thermo Fisher Scientific, MA, USA), 10\% FBS (0437028, Gibco, MD, USA), 1\% 123 penicillin/streptomycin (P/S - 15140122, Gibco, MD, USA), $50 \mu \mathrm{g} / \mathrm{mL}$ ascorbic acid (AA 124 97061-072, VWR, PA, USA), 0.5\% Amphotericin B (FZ - 15290018, Gibco, MD, USA)) in 5\% $125 \mathrm{CO}_{2}, 20.7 \% \mathrm{O}_{2}$ at $37^{\circ} \mathrm{C}$, and fed every 3 days until $80 \%$ confluent. Cells were used at passage $\leq \mathrm{p} 4$. 126 Pellet Culture

127 Please refer to Table 1 and Figure 1 for study design. CEP cells were pelleted at $1 \times 10^{6}$ cells/pellet 128 in $15 \mathrm{~mL}$ falcon tubes by centrifuging at $400 x \mathrm{x}$ for 5 minutes and cultured in $2 \mathrm{~mL}$ of either 1) 129 Chondrogenic (DMEM, 4.5g/L glucose, 1\% P/S, 1X ITS (I2771, Sigma Aldrich, MO, USA), 130

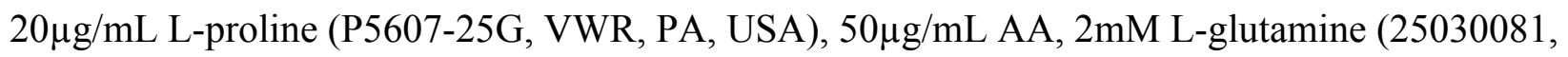
131 Gibco, MD, USA), 1mM sodium pyruvate (11360070, Gibco, MD, USA), 10-7 M dexamethasone 132 (D4902-25MG, Millipore Sigma, MA, USA), 10ng/mL Recombinant TGF- $\beta 3$ (from E.coli 133 10778-940, VWR, PA, USA) $\left.{ }^{32}\right)$, 2) 10\% FBS (10\% FBS, DMEM, 4.5g/L glucose, 1\% P/S, 10mM

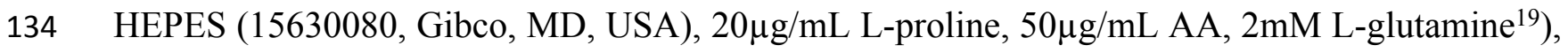
135 3) Wnt agonist (1X ITS, DMEM, 4.5g/L glucose, $1 \% \mathrm{P} / \mathrm{S}, 10 \mathrm{mM}$ HEPES, $20 \mu \mathrm{g} / \mathrm{mL}$ L-proline, 
$50 \mu \mathrm{g} / \mathrm{mL}$ AA, 2mM L-glutamine, 0.5 $\mathrm{M}$ Wnt Agonist (CHIR99021, Stemcell Technologies, Vancouver, CA)) added fresh ${ }^{20}$ ) or 4) Basal (1X ITS, DMEM, 4.5g/L glucose, 1\% P/S, 10mM HEPES, $20 \mu \mathrm{g} / \mathrm{mL}$ L-proline, $50 \mu \mathrm{g} / \mathrm{mL}$ AA, $2 \mathrm{mM}$ L-glutamine) media ( $\mathrm{n}=10$ Chondrogenic, $\mathrm{n}=10$ $10 \% \mathrm{FBS}, \mathrm{n}=10 \mathrm{Wnt}$ agonist, $\mathrm{n}=7$ Basal) for 21 days in $\mathbf{5 \%} \mathbf{O}_{\mathbf{2}}, 5 \% \mathrm{CO}_{2}(\mathrm{n}=10)$ or $\mathbf{2 0 . 7 \%} \mathbf{O}_{\mathbf{2}}, 5 \%$ $\mathrm{CO}_{2}(\mathrm{n}=5)$ at $37^{\circ} \mathrm{C}$ with media changes every 3-4 days. Cell viability was assessed by incubating pellets for 20 minutes in DMEM containing Calcein AM $(2 \mu \mathrm{M})(\mathrm{C} 1430$, Thermo Fisher Scientific, MA, USA)/Ethidium homodimer-1 (1 $\mu \mathrm{M})$ (E1169, Thermo Fisher Scientific, MA, USA). A 20x fluorescent image of each pellet was taken using a Nikon TiE Inverted Microscope with a highresolution DS-Qi2 camera to qualitatively determine live and dead cells.

\section{Pellet Size, Matrix Composition and Cell Morphology}

Pellets (Treatment: Chondrogenic $(n=7)$, Basal $(n=7), 10 \%$ FBS $(n=6)$, Wnt agonist $(n=7)$; Oxygen level: $\left.20.7 \% \mathrm{O}_{2}(\mathrm{n}=4), 5 \% \mathrm{O}_{2}(\mathrm{n}=6)\right)$ were fixed in $10 \%$ neutral buffered formalin for 24 hours, dehydrated, then embedded in paraffin and cut into $4 \mu \mathrm{m}$ sections. Pellet size and cell morphology were evaluated using hematoxylin and eosin $(\mathrm{H} \& \mathrm{E})$ as previously described ${ }^{33}$. Pellet size was quantified using the manual measurements tool in Nikon NIS-Elements AR software and area measured in millimeters squared. Hypertrophic cell morphology was determined by qualitatively evaluating $H \& E$ stained pellets for enlarged/vacuolated hypertrophic cells ${ }^{19-23}$. To determine matrix composition, the sections were stained using a picrosirius red (collagen)/alcian blue (proteoglycan) (PRAB) dual stain $^{33}$. Stained pellets were imaged using a Nikon TiE Inverted Microscope with a high-resolution DS-U3 camera at 10x or 20x magnification.

\section{Quantification of Glycosaminoglycan content}

Pellets (Treatment: Chondrogenic $(n=9)$, Basal $(n=10), 10 \%$ FBS $(n=9)$, Wnt agonist $(n=9)$; Oxygen level: $\left.20.7 \% \mathrm{O}_{2}(\mathrm{n}=6), 5 \% \mathrm{O}_{2}(\mathrm{n}=5)\right)$ were digested in $400 \mu \mathrm{L}$ of papain digest $(125 \mu \mathrm{g} / \mathrm{mL}$ 
159 papain (from Papaya latex - P4762, Sigma-Aldrich, MO, USA), 0.1M sodium phosphate 160 monobasic monohydrate (71507-250G, Sigma-Aldrich, MO, USA), 5mM EDTA (E9884-1KG, 161 Sigma-Aldrich, MO, USA), 5mM L-cysteine hydrochloride (2430-100GM, Millipore Sigma, MA, 162 USA)) and incubated in $65^{\circ} \mathrm{C}$ overnight. Digested samples were used for dimethylmethylene blue 163 (DMMB) assay to assess glycosaminoglycan (GAG) content ${ }^{34}$. DNA content was assessed using 164 a DNA Quantitation Kit (DNAQF, Sigma Aldrich, MO, USA) per manufacturer's instructions. 165 GAG content was normalized to DNA content.

166 167 168 169 170 171 172 173 174 175 176 177 178 179 180 181

\section{Quantification of Gene Expression}

To determine relative gene expression, qRT-PCR was performed for all groups (Treatment: Chondrogenic $(n=7-9)$, Basal $(n=7), 10 \%$ FBS $(n=7-9)$, Wnt agonist $(n=7-10)$; Oxygen level: 20.7\% $\left.\mathrm{O}_{2}(\mathrm{n}=5), 5 \% \mathrm{O}_{2}(\mathrm{n}=7)\right)$. TRIzol Plus RNA Purification Kit (12183555, Thermo Fisher Scientific, MA, USA) was used to isolate RNA and RNA was quantified using the Nanodrop 2000. Samples were reverse-transcribed to cDNA using qScript XLT cDNA SuperMix (95161, Quanta Biosciences, UT, USA) or Maxima H Minus cDNA Synthesis Master Mix (M1662, Thermo Fisher Scientific, MA, USA) and diluted to a final concentration of $15 \mathrm{ng} /$ reaction. QRT-PCR was completed in duplicate using Taqman Master Mix and primers (Table 2). Gene expression was determined using the $\Delta \Delta \mathrm{CT}$ method relative to the housekeeping gene $18 \mathrm{~s}^{31}$.

\section{Immunohistochemical analysis for MMP-13 and COLX expression}

Immunohistochemistry (IHC) was performed on formalin fixed, paraffin embedded and sectioned pellets (Treatment: Chondrogenic $(n=7)$, Basal $(n=7), 10 \%$ FBS $(n=6)$, Wnt agonist $(n=7)$; Oxygen level: $\left.20.7 \% \mathrm{O}_{2}(\mathrm{n}=4), 5 \% \mathrm{O}_{2}(\mathrm{n}=6)\right)$. Slides were deparaffinized and rehydrated. Antigen retrieval was performed using 1X Dako Target Retrieval Solution (S169984-2, Agilent Technologies, CA, USA) preheated in a steamer. Slides were added to pre-heated solution and steamed for 15 
182 (MMP13) or 20 minutes (COLX). Slides were cooled to room temperature and washed $2 \times 5$ 183 184 185 186 187 188 189 190 191 192 193 194 195 196 197 minutes. Slides were treated with Dako Protein Block (X090930-2, Agilent Technologies, CA, USA) solution for 15 (MMP13) or 20 minutes (COLX). Slides were incubated with primary antibody for MMP-13 (LS-B3168-50, LifeSpan BioSciences Inc, WA, USA - recognizes proenzyme and cleaved fragments) diluted at a 1:1300 dilution overnight at $4{ }^{\circ} \mathrm{C}$, or antibody for COLX (LS-B14811, LifeSpan BioSciences Inc, WA, USA) diluted at 1:100 for 45 minutes in Dako Antibody Diluent (S302283-2, Agilent Technologies, CA, USA) at room temperature. A no primary antibody control was used for each round of staining. Slides were washed for $3 \times 5$ minutes. Endogenous peroxidases were blocked by incubating slides in 3\% hydrogen peroxide (H1009100ML, Millipore Sigma, MA, USA) in methanol (NC1270520, Thermo Fisher Scientific, MA, USA) for 10 minutes (MMP13) or 15 minutes (COLX). Slides were washed for $2 \times 5$ minutes and incubated for 30 minutes in Vector Biotinylated Goat Anti-Rabbit IgG Antibody (H+L) (BA-1000, Vector Laboratories, CA, USA) diluted 1:200 in Dako Protein Block at room temperature. Slides were washed for $3 \times 5$ minutes and incubated for 30 minutes in R.T.U. Horseradish Peroxidase Streptavidin (SA-5704, Vector Laboratories, CA, USA) at room temperature. Slides were washed for $3 \times 5$ minutes and treated with 3, 3'-Diaminobenzidine for 5 minutes using the ImmPACT DAB Peroxidase (HRP) Substrate kit (SK-4105, Vector Laboratories, CA, USA). Slides were rinsed with deionized water for 5 minutes, counterstained with Gills Hematoxylin No.2 (GHS232-1L, Millipore Sigma, MA, USA), rinsed with deionized water, and blued in bluing solution for 30 seconds (0.05\% ammonium hydroxide (C993P14, Electron Microscopy Sciences, PA, USA) in water). Slides were dehydrated, cleared in xylene (HC-700-1GAL, Thermo Fisher Scientific, MA, USA), and mounted using Cytoseal Mounting Medium (23-244-257, Thermo Fisher Scientific, 
204 MA, USA). Stained pellets were imaged using a Nikon TiE Inverted Microscope with a high-

205 resolution DS-U3 camera at 20x magnification.

206 Quantification of MMP-13 and COLX

$20720 \mathrm{X}$ images (1-3 images depending on pellet size) were used to quantify staining. Images were 208 taken from both the pellet center and periphery. Slides were blinded before imaging and remained 209 blinded throughout image analysis. The IHC Profiler plugin for ImageJ was used to quantify 210 staining. The IHC Profiler plugin ${ }^{35}$ reports percent contribution of high positive, positive, low 211 positive and negative cells. Based on this information, an H-score from 0-300 (300 being 100\% 212 high positivity and 0 being completely negative) was calculated for each image using Equation 1.

$$
\mathrm{H} \text {-score }=(\% \text { high positive } \mathrm{x} 3)+(\% \text { positive } \mathrm{x} 2)+(\% \text { low positive } \mathrm{x} 1)
$$

\section{$214 \quad$ Statistics}

215 All data was transformed using a Box Cox Transformation with optimal $\lambda$ that minimizes the sum

216 of squared error to achieve normality. A two-way ANOVA was used to assess the main effects of

217 media treatment and oxygen condition, as well as the interaction between media treatment and 218 oxygen condition. An Anderson-Darling test was performed on the data residuals to confirm 219 normally distributed data. Post-hoc Tukey tests were used to determine which specific groups 220 differed if the main effect of treatment or interaction was significant. All test were conducted using 221 Minitab with $\alpha=0.05$ and $p<0.05$ was considered significant.

222 Results:

223 Viability

224 Viable cells (and some dead cells) were observed in all treatment groups and oxygen conditions 225 (Figure 2). Due to the high cell density of the pellets, quantifiable viability data could not be 
226 obtained and viability was assessed qualitatively. No qualitative differences were observed 227 between groups.

\section{Pellet Size, Matrix Composition and Cell Morphology}

229 Pellet area was significantly reduced in the 10\% FBS group compared to the Basal control (Figure $2303 \mathrm{a}$ and $\mathrm{b}$ ). Enlarged hypertrophic cell morphology was not observed in any of the groups (Figure 231 4). PRAB staining of cell pellets demonstrated a reduction in proteoglycan assessed by a decrease 232 in alcian blue staining observed in the 10\% FBS and Wnt agonist groups compared to the Basal 233 group (Figure 2a). This was supported quantitatively by the results of the DMMB assay which 234 revealed significant differences in proteoglycan (glycosaminoglycan (GAG)) content between 235 treatment groups (Figure 5a-c). Significant decreases in GAG/DNA were measured in the 10\% 236 FBS and Wnt agonist groups compared to the Chondrogenic group. A significant reduction in

237 GAG/DNA was observed in the $10 \%$ FBS group relative to the Basal (Figure 5a). There was no 238 significant difference in GAG/DNA content measured between oxygen conditions (Figure 5a); 239 however, there were differences in raw (not normalized) GAG and DNA between oxygen groups 240 (Figure 5 b-c). Significant interactions between oxygen levels and treatment groups in GAG/DNA 241 content and DNA content were observed and are shown in Figure $5 \mathrm{a}$ and c.

\section{Gene Expression}

243 QRT-PCR demonstrated significant differences in matrix marker, hypertrophic marker and 244 angiogenic/inflammatory marker gene expression between different oxygen conditions (Figure 245 6a). There was a significant up-regulation in COL2, SOX9, IHH, RUNX2 and IL6 in the 5\% $\mathrm{O}_{2}$ 246 group compared to $20.7 \% \mathrm{O}_{2}$. There was a significant down-regulation in MMP-13 in the $5 \% \mathrm{O}_{2}$ 247 group compared to $20.7 \% \mathrm{O}_{2}$ and no difference in VEGF, NGF or TAC1 expression between 248 oxygen conditions (Figure 6a). Media treatments also had a significant effect on expression of 
249

250

251

252

253

254

255

256

257

258

259

260

261

262

263

264

265

266

267

268

269

270

271

matrix marker, hypertrophic marker and inflammatory markers (Figure 6b). There was a significant up-regulation of COL2 in the Chondrogenic group and a significant down-regulation in COL2 in the $10 \%$ FBS group compared to the Basal control. There was a significant upregulation of COLX and SPP1 and significant down-regulation of RUNX2 in the Chondrogenic group, a significant up-regulation in IHH, RUNX2, MMP13, and COLX in the $10 \%$ FBS group, and significant up-regulation of RUNX2 and MMP13 in with Wnt agonist group compared to the Basal control. There was a significant down-regulation in VEGF, NGF and IL6 in the Chondrogenic group, significant up-regulation of IL1 $\beta$ in the $10 \%$ FBS group, and significant upregulation of IL6 in the Wnt agonist group compared to the Basal control (Figure 6b). There were significant interactions between media treatment and oxygen conditions in SOX9, IHH and RUNX2 expression (Figure 6c).

\section{Immunohistochemistry}

Protein expression of MMP13 and COLX (both markers of hypertrophy) was evaluated due to large differences in MMP-13 and COLX gene expression between treatment groups. No effect of image location (center vs periphery) was observed for either protein. Interestingly, IHC for MMP-

13 and COLX revealed no significant differences in protein expression between treatment or oxygen conditions as shown in Figure 7 and Figure 8.

\section{Discussion:}

The initiation and progression of IVD degeneration and LBP is highly associated with degenerative changes to the CEP, such as CEP calcification ${ }^{6}$, and hypertrophic differentiation of CEP cells has been identified as one potential mechanism of this process ${ }^{15}$. The goal of this study was to investigate the role of culture conditions on hypertrophic differentiation in human cartilage endplate cells. Both Wnt agonist and 10\% fetal bovine serum (FBS) have been used to 
272 induce hypertrophic differentiation in articular chondrocytes in vitro ${ }^{19-23}$. As such, we explored

273 the effects of Wnt agonist and 10\% FBS on CEP cells. Interestingly, unlike articular

274 chondrocytes, CEP cells did not exhibit a hypertrophic cell morphology in response to $10 \%$ FBS

275 or Wnt agonist but displayed other hallmarks of chondrocyte hypertrophy and degeneration such

276 as hypertrophic gene and protein expression, and a decrease in healthy proteoglycan and an

277 increase in fibrous collagen accumulation.

278

Based on previous studies demonstrating $10 \%$ FBS induces hypertrophic differentiation

279 in articular chondrocytes, we hypothesized addition of $10 \%$ FBS to CEP cells would also induce

280 hypertrophic differentiation. Our histological data showed no morphological evidence of

281 hypertrophic differentiation in CEP cells treated with 10\% FBS after 21 days, whereas past

282 studies found that articular chondrocytes take on a large, vacuolated hypertrophic morphology in

283 pellet culture in response to $10 \% \mathrm{FBS}$ at this timepoint ${ }^{19,21-23}$. These differences in response to

284 the same stimuli may be due to differences in cell phenotype between CEP cells and articular

285 chondrocytes which we recently demonstrate on the gene level ${ }^{35,36}$. However, we did observe a

286 decrease in COL2, an increase in IL1- $\beta$, MMP13, RUNX2, IHH and COLX gene expression,

287 and decrease in both pellet size and GAG content in the 10\% FBS group compared to the Basal

288 control. These findings are consistent with previous studies which found increased expression of

289 COLX, MMP13, RUNX2 and decreased expression of COL2 ${ }^{19,21}$, GAG content and pellet size in

290 articular chondrocytes ${ }^{38}$ treated with $10 \%$ FBS.

291 We also hypothesized that addition of Wnt agonist to CEP cells would induce

292 hypertrophic differentiation due to the role of the Wnt/ $\beta$-catenin pathway in modulating this

293 process $^{20}$. We observed no characteristic morphological changes indicative of hypertrophic

294 differentiation in the CEP cells treated with Wnt agonist after 21 days. We observed an increase 
295 in RUNX2 and MMP13 gene expression with Wnt agonist compared to Basal, but saw no 296 significant effects of Wnt agonist on any other dependent variables. Enochson et al. also found a 297 significant increase in MMP13 gene and protein expression in chondrocyte pellets treated with 298 Wnt agonist ${ }^{20}$. However, when we examined MMP13 in CEP pellets on the protein level, we 299 found no significant differences between groups, suggesting differing effects of Wnt agonist on 300 the CEP compared to articular chondrocytes. Furthermore, chondrogenic media containing TGF- $\beta 3$ has long been used to maintain a 302 chondrogenic phenotype in articular chondrocyte cells in in vitro culture systems ${ }^{32,39,40}$ and we 303 hypothesized that it would maintain a healthy CEP cell phenotype in our culture model. TGF- $\beta 3$ 304 is known to play a role in cartilage development and maintenance and has been shown to inhibit 305 expression of osteogenic and angiogenic markers such as RUNX2, MMP13, COLX and VEGF ${ }^{41}$. 306 In alignment with previous findings, we observed a significant down-regulation of VEGF and 307 NGF gene expression and increase in healthy proteoglycan accumulation (GAG) in the 308 Chondrogenic group compared to the Basal, likely indicating a pro-anabolic/anti309 angiogenic/neurogenic role for TGF- $\beta$ in our culture system. On the contrary, we also observed a 310 significant increase in gene expression of hypertrophic markers COLX and SPP1 in our 311 Chondrogenic group compared to our Basal control, which was surprising but further highlights 312 potential differences in the response of CEP versus articular chondrocyte cells to the same 313 stimuli. Hypertrophic markers MMP13 and COLX were examined on the protein level using IHC 315 to validate our gene expression findings. Interestingly we found that cell pellets from all 316 treatment groups express COLX and MMP13 protein with no significant differences between 317 treatment groups. This did not correlate with our findings on the gene level, demonstrating a 
318 potential disconnect between gene and protein expression in our culture system. The presence of

319 COLX protein, a distinct hypertrophic marker, in CEP cells without a morphological

320 hypertrophic phenotype was surprising. Though, COLX protein expression at the CEP-vertebral

321 body interface in cadaveric human specimens ranging from very young fetuses to adults of 86

322 years of age has been previously demonstrated ${ }^{42}$, suggesting that CEP cells actually express

323 baseline levels of COLX protein irrespective of a healthy or diseased state. This is supported by

324 the expression of COLX in all treatment and control groups at the gene and protein level.

325 Interestingly, studies to date examining hypertrophic differentiation in the CEP utilize common

326 markers of articular chondrocyte hypertrophy as evidence of hypertrophic differentiation but

327 have not examined CEP cell morphology ${ }^{15-18,43}$. These studies together with our current work

328 suggest that CEP cells may express hypertrophic markers without the characteristic changes in

329 morphology seen in typical hypertrophic articular chondrocytes.

In addition, CEP cell pellets were cultured in both physiologic $\left(5 \% \mathrm{O}_{2}\right)$ oxygen levels experienced by cartilage and hyperoxic $\left(20.7 \% \mathrm{O}_{2}\right)$ oxygen levels. We hypothesized that $20.7 \%$

$332 \mathrm{O}_{2}$ would result in greater hypertrophic differentiation of CEP cells in response to $10 \% \mathrm{FBS}$ or

333 Wnt agonist but saw no morphological evidence of hypertrophic CEP cells regardless of oxygen

334 level. Findings related to oxygen level were variable, with increased gene expression of COL2

335 and decreased expression of MMP13 in 5\% $\mathrm{O}_{2}$ compared to $20.7 \% \mathrm{O}_{2}$. However, we also

336 observed a significant increase in additional hypertrophic markers RUNX2 and IHH, and

337 inflammatory marker IL6 in the $5 \% \mathrm{O}_{2}$ condition that further demonstrates differential responses

338 of CEP cells and articular chondrocytes to the same culture conditions.

This study provides insight into regulation of CEP cell differentiation. Using biochemical 
341 were unable to observe a classical hypertrophic cell morphology in CEP cells. We observed

342 increased gene expression of hypertrophic markers in response to $10 \% \mathrm{FBS}$ and Wnt agonist

343 however, these changes were not observed at the protein level for the markers MMP13 and

344 COLX we evaluated using IHC. Since gene expression and hypertrophic differentiation are

345 temporal in nature, this may indicate a missed timepoint in our culture model. The 21 day culture

346 period we utilized is a common culture time used to induce hypertrophic differentiation in

347 articular chondrocytes ${ }^{19,21-23}$, although CEP cells may behave differently and undergo

348 hypertrophic differentiation in a different time frame. Examining a single time point can be

349 considered a potential limitation of the current study. Addition of an articular chondrocyte

350 control to directly compare CEP and articular chondrocyte cell behavior in vitro and increasing

351 sample size in order to further validate the effect of culture conditions and oxygen tension on sex

352 and age-related differences in human CEP samples would enhance the rigor of the current study.

353 Extreme care taken when separating CEP, AF and NP tissue during dissection, and previously

354 observed differences in marker expression at the gene level between cells using the same

355 isolation technique, suggest isolation of distinct cell populations ${ }^{36,37}$. Nevertheless, cross-

356 contamination with additional cell types, such as inflammatory cells, could still be a minimal

357 concern. In addition, exploring the effects of the mechanical microenvironment on the CEP,

358 which has been previously shown to modulate CEP cell phenotype ${ }^{40}$, is an area of interest that

359 warrants further investigation. Furthermore, one past study shows that exposing human CEP

360 cells to free calcium impairs CEP homeostasis and promotes a catabolic phenotype, similar to

361 that of our $10 \%$ FBS condition, with a decrease in secreted GAG and COL2 ${ }^{44}$. Unfortunately,

362 hypertrophic differentiation of CEP cells in response to free calcium was not explored, but could

363 be an alternative to the hypertrophic stimuli used in the current study due to its role in 
364 hypertrophic differentiation of articular chondrocytes ${ }^{45}$. These considerations, while important, 365 were outside the scope of the current study but may be explored in future studies.

366 Conclusion:

This study evaluated the effects of culture conditions on hypertrophic differentiation in

368 CEP cells in vitro in attempt to better understand mechanisms involved in CEP

369 degeneration/calcification. We implemented common methods used to induce hypertrophic 370 differentiation in articular chondrocytes, which included treatment with 10\% FBS and Wnt 371 agonist. Additionally, we examined two oxygen levels $\left(5 \% \mathrm{O}_{2}\right.$ and $\left.20.7 \% \mathrm{O}_{2}\right)$ to further evaluate 372 culture conditions that may affect CEP cell hypertrophy. Surprisingly, we were unable to induce 373 a classical hypertrophic cell morphology in CEP cells at either oxygen level which may indicate

374 key differences in the physiology of CEP cells compared to articular chondrocytes. Additionally, 375 the distinct differences in response between CEP cells and articular chondrocytes to hypertrophic 376 stimuli highlighted by this work and the literature demonstrates a need to further understand 377 mechanisms of how CEP cells contribute to calcification since it is known to be an important 378 contributor to IVD degeneration.

379 Acknowledgements:

380 The authors would like to acknowledge Dr. Connor Buckley and Dr. James Rathman for their 381 technical assistance and Dr. William Marras and The Ohio State University Spine Research 382 Institute for their support. The authors would also like to acknowledge Emma Wittman and 383 Gilian Gunsch for their assistance with data collection. This study was funded internally through 384 the Department of Biomedical Engineering and College of Engineering at The Ohio State 385 University. The authors have no professional or financial affiliations to disclose. 


\section{References:}

1. GBD 2017 DALYs and HALE Collaborators. 2018. Global, regional, and national disability-adjusted life-years (DALYs) for 359 diseases and injuries and healthy life expectancy (HALE) for 195 countries and territories, 1990-2017: a systematic analysis for the Global Burden of Disease Study 2017. Lancet 392: 1859-1922.

2. Ringwalt C, Gugelmann H, Garrettson M, et al. 2014. Differential prescribing of opioid analgesics according to physician specialty for Medicaid patients with chronic noncancer pain diagnoses. Pain Res Manag 19: 179-185.

3. Katz JN. 2006. Lumbar disc disorders and low-back pain: socioeconomic factors and consequences. J Bone Joint Surg Am 88 Suppl 2: 21-24.

4. Balagué F, Mannion AF, Pellisé F, Cedraschi C. 2012. Non-specific low back pain. Lancet 379: 482-491.

5. Chan WC, Sze KL, Samartzis D, Leung VY, Chan D. 2011. Structure and biology of the intervertebral disk in health and disease. Orthop Clin North Am 42: 447-464.

6. Grunhagen T, Shirazi-Adl A, Fairbank JC, Urban JP. 2011. Intervertebral disk nutrition: a review of factors influencing concentrations of nutrients and metabolites. Orthop Clin North Am 42: 465-477.

7. Antoniou J, Goudsouzian NM, Hathfield TF, et al. 1996. The human lumbar endplate: evidence of changes in biosynthesis and denaturation of the extracellular matrix with growth, maturation, aging, and degeneration. Spine (Phila Pa 1976) 21: 1153-1161.

8. Roberts S, Menage J, Urban JP. 1989. Biochemical and structural properties of the cartilage end-plate and its relation to the intervertebral disc. Spine (Phila Pa 1976) 14: $166-174$. 
9. Wong J, Sampson SL, Bell-Briones H, et al. 2019. Nutrient supply and nucleus pulposus cell function: effects of the transport properties of the cartilage endplate and potential implications for intradiscal biologic therapy. Osteoarthritis Cartilage 27: 956964.

10. Fields AJ, Liebenberg EC, Lotz JC. 2014. Innervation of pathologies in the lumbar vertebral end plate and intervertebral disc. Spine J 14: 513-21.

11. Dudli S, Liebenberg E, Magnitsky S, Lu B, Lauricella M, Lotz JC. 2018. Modic type 1 change is an autoimmune response that requires a proinflammatory milieu provided by the 'Modic disc'. Spine J. 18: 831-844.

12. Dudli S, Fields AJ, Samartzis D, Karppinen J, Lotz JC. 2016. Pathobiology of modic changes. Eur Spine J 25: 3723-3734.

13. Bailey JF, Fields AJ, Ballatori A, Cohen D, et al. 2019. The relationship between endplate pathology and patient-reported symptoms for chronic low back pain depends on lumbar paraspinal muscle quality. Spine (Phila Pa 1976) 44: 1010-1017.

14. Dolor A, Sampson SL, Lazar AA, et al. 2019. Matrix modification for enhancing the 425 transport properties of the human cartilage endplate to improve disc nutrition. PLoS One 14: e0215218. AGEs induce ectopic endochondral ossification in intervertebral discs. Eur Cells Mater. 32: 257-270.

16. Xiao ZF, He JB, Su GY, Chen MH, Hou Y, Chen SD, Lin DK. 2018. Osteoporosis of the vertebra and osteochondral remodeling of the endplate causes intervertebral disc degeneration in ovariectomized mice. Arthritis Res Ther. 20: 207. on in 
ovariectomized mice. Arthritis Res. Ther. 20, 207 (2018).

17. Han YC, Ma B, Guo S, Yang M, Li LJ, Wang SJ, Tan J. 2018. Leptin regulates disc cartilage endplate degeneration and ossification through activation of the MAPK-ERK signalling pathway in vivo and in vitro. J Cell Mol Med. 22: 2098-2109.

18. Liu S, Zhao B, Shi H, et al. 2016. Ligustrazine inhibits cartilage endplate hypertrophy via suppression of TGF- $\beta 1$. Evid Based Complement Alternat Med. 2016: 1042489.

19. Pesesse L, Sanchez C, Delcour JP, et al. 2013. Consequences of chondrocyte 
of oxygen levels on proteoglycan synthesis by intervertebral disc cells. Spine (Phila Pa 1976). 36: E131-E138.

25. Feng G, Li L, Liu H, et al. 2013. Hypoxia differentially regulates human nucleus pulposus and annulus fibrosus cell extracellular matrix production in 3D scaffolds.

Osteoarthritis Cartilage 21: 582-588.

26. Jaworski LM, Kleinhans KL, Jackson AR. 2019. Effects of oxygen concentration and culture time on porcine nucleus pulposus cell metabolism: an in vitro study. Front Bioeng Biotechnol. 7: 64.

27. Yang SH, Hu MH, Sun YH, Lin FH. 2013. Differential phenotypic behaviors of human degenerative nucleus pulposus cells under normoxic and hypoxic conditions: influence of oxygen concentration during isolation, expansion, and cultivation. Spine J. 13: 1590-1596.

28. Leijten JC, Moreira Teixeira LS, Landman EB, van Blitterswijk CA. Karperien M. 2012. Hypoxia inhibits hypertrophic differentiation and endochondral ossification in explanted tibiae. PLoS One 7: e49896.

29. Yao Y, Deng Q, Song W, et al. 2016. MIF plays a key role in regulating tissuespecific chondro-osteogenic differentiation fate of human cartilage endplate stem cells under hypoxia. Stem cell reports 7: 249-62.

30. Thompson JP, Pearce RH, Schechter MT, et al. 1990. Preliminary evaluation of a scheme for grading the gross morphology of the human intervertebral disc. Spine (Phila Pa 1976) 15: 411-415.

31. Purmessur D, Shek RM, Abbott RD, et al. 2011. Notochordal conditioned media from tissue increases proteoglycan accumulation and promotes a healthy nucleus pulposus 
phenotype in human mesenchymal stem cells. Arthritis Res Ther 13: R81.

32. Mackay AM, Beck SC, Murphy JM, et al. 1998. Chondrogenic differentiation of cultured human mesenchymal stem cells from marrow. Tissue Eng. 4: 415-428.

33. Walter BA, Torre OM, Laudier D, et al. 2015. Form and function of the intervertebral disc in health and disease: A morphological and stain comparison study. J Anat. 227: 707-716.

34. Luo XW, Liu K, Chen Z, et al. 2016. Adenovirus-mediated GDF-5 promotes extracellular matrix expression in degenerative nucleus pulposus cells. J Zhejiang Univ Sci B. 17: 30-42.

35. Varghese F, Bukhari AB, Malhotra R, De A. 2014. IHC profiler: an open source plugin for the quantitative evaluation and automated scoring of immunohistochemistry images of human tissue samples. PLoS One 9: e96801.

36. Lakstins K, Arnold L, Gunsch G, et al. 2020. Characterization of the human intervertebral disc cartilage endplate at the molecular, cell and tissue level. J Orthop Res: in review.

37. Lakstins K, Arnold L, Gunsch G, et al. 2020. Characterization of the human intervertebral disc cartilage endplate at the molecular, cell and tissue level. Orthopaedic Research Society Annual Meeting: Abstract.

38. Liu X, Liu J, Kang N, et al. 2014. Role of insulin-transferrin-selenium in auricular chondrocyte proliferation and engineered cartilage formation in vitro. Int J Mol Sci. 15: $1525-1537$.

39. Miyanishi K, Trindade MC, Lindsey DP, et al. 2006. Effects of hydrostatic pressure and transforming growth factor-beta 3 on adult human mesenchyman stem cell 
502

503

504

505

506

507

508

509

510

511

512

513

514

515

516

517

518

519

520

521

522

523

524

chondrogenesis in vitro. Tissue Eng. 12: 1419-1428.

40. Thorpe SD, Buckley CT, Vinardell T, et al. 2010. The Response of bone marrowderived mesenchymal stem cells to dynamic compression following TGF-beta3 induced chondrogenic differentiation. Ann Biomed Eng 38: 2896-2909.

41. Zhang X, Ziran N, Goater JJ, et al. 2004. Primary murine limb bud mesenchymal cells in long-term culture complete chondrocyte differentiation: TGF-beta delays hypertrophy and PGE2 inhibits terminal differentiation. Bone 34: 809-817.

42. Aigner T, Gresk-otter KR, Fairbank JC, et al. 1998. Variation with age in the pattern of type X collagen expression in normal and scoliotic human intervertebral discs. Calcif Tissue Int 63: 263-268.

43. Bian Q, Liang QQ, Wan C, et al. 2011. Prolonged upright posture induces calcified hypertrophy in the cartilage end plate in rat lumbar spine. Spine (Phila Pa 1976) 36: 2011-2020.

44. Grant MP, Epure LM, Bokhari R, et al. 2016. Human cartilaginous endplate degeneration is induced by calcium and the extracellular calcium-sensing receptor in the intervertebral disc. Eur Cell Mater 32: 137-151.

45. Studer D, Millan C, Öztürk E, et al. 2012. Molecular and biophysical mechanisms regulating hypertrophic differentiation in chondrocytes and mesenchymal stem cells. Eur Cells Mater 24: 118-135.

\section{Table Captions:}

Table 1: Demographics for cadaveric specimens used and breakdown of study design, including which specimens were utilized in each group and overall sample sizes.

Table 2: Genes and corresponding description of genes evaluated using qRT-PCR. 


\section{Figure Legends:}

526 Figure 1: Overall study design with independent and dependent variables and methods used to

527 assess each dependent variable.

528 Figure 2: Representative images of cell viability where human cartilage endplate cells stained in 529 green are alive and cells stained in red are dead. Scale bar $=100 \mu \mathrm{m}$

530 Figure 3: Picrosirius red (collagen) and alcian blue (proteoglycan) staining of CEP cell pellets 531 demonstrating differences in proteoglycan and collagen matrix accumulation between

532 Chondrogenic, Basal, 10\% FBS and Wnt agonist treatment groups, Scale bar $=500 \mu \mathrm{m}$ (a).

533 Quantified pellet area in millimeters squared showing the main effects of oxygen levels and

534 treatment groups and the interaction between oxygen levels and treatment groups (b). Different

535 letters represent statistically significant differences $(\mathrm{p}<0.05)$, error bars represented as SEM.

536 Figure 4: Representative images of hematoxylin and eosin stained CEP cells to evaluated

537 changes in cell morphology in different treatment groups and oxygen levels. Scale bar $=50 \mu \mathrm{m}$.

538 Figure 5: Main effects of Chondrogenic, Basal, 10\% FBS and Wnt agonist media treatments and

539 oxygen levels and interactions between media treatments and oxygen levels for normalized

540 GAG/DNA (a), raw GAG (b), and raw DNA (c) content in CEP pellets after 21 days. Different

541 letters represent statistically significant differences $(\mathrm{p}<0.05)$, error bars represented as SEM.

542 Figure 6: Main effects of oxygen levels (a) and Chondrogenic, Basal, 10\% FBS and Wnt agonist 543 media treatments (b) on matrix, bone and neurovascular \& inflammatory marker gene expression

544 in CEP pellets after 21 days. Significant interactions between media treatments and oxygen

545 levels on SOX9, IHH and RUNX2 gene expression in CEP pellets after 21 days (c). Different

546 letters represent statistically significant differences $(\mathrm{p}<0.05)$, error bars represented as SEM. 
547 Figure 7: Representative images of MMP-13 IHC in CEP pellets and no primary control, Black

548 Scale $=100 \mu \mathrm{m}$, Red Scale $=50 \mu \mathrm{m}$. Main effects of Chondrogenic, Basal, 10\% FBS and Wnt

549 agonist media treatments and oxygen levels and interactions between media treatments and

550 oxygen levels on quantified MMP-13 protein expression represented as H-Score. Different letters

551 represent statistically significant differences $(\mathrm{p}<0.05)$, error bars represented as SEM.

552 Figure 8: Representative images of COLX IHC in CEP pellets and no primary control, Black

553 Scale $=100 \mu \mathrm{m}$, Red Scale $=50 \mu \mathrm{m}$. Main effects of Chondrogenic, Basal, 10\% FBS and Wnt

554 agonist media treatments and oxygen levels and interactions between media treatments and

555 oxygen levels on quantified COLX protein expression represented as H-Score. Different letters

556 represent statistically significant differences $(\mathrm{p}<0.05)$, error bars represented as SEM. 


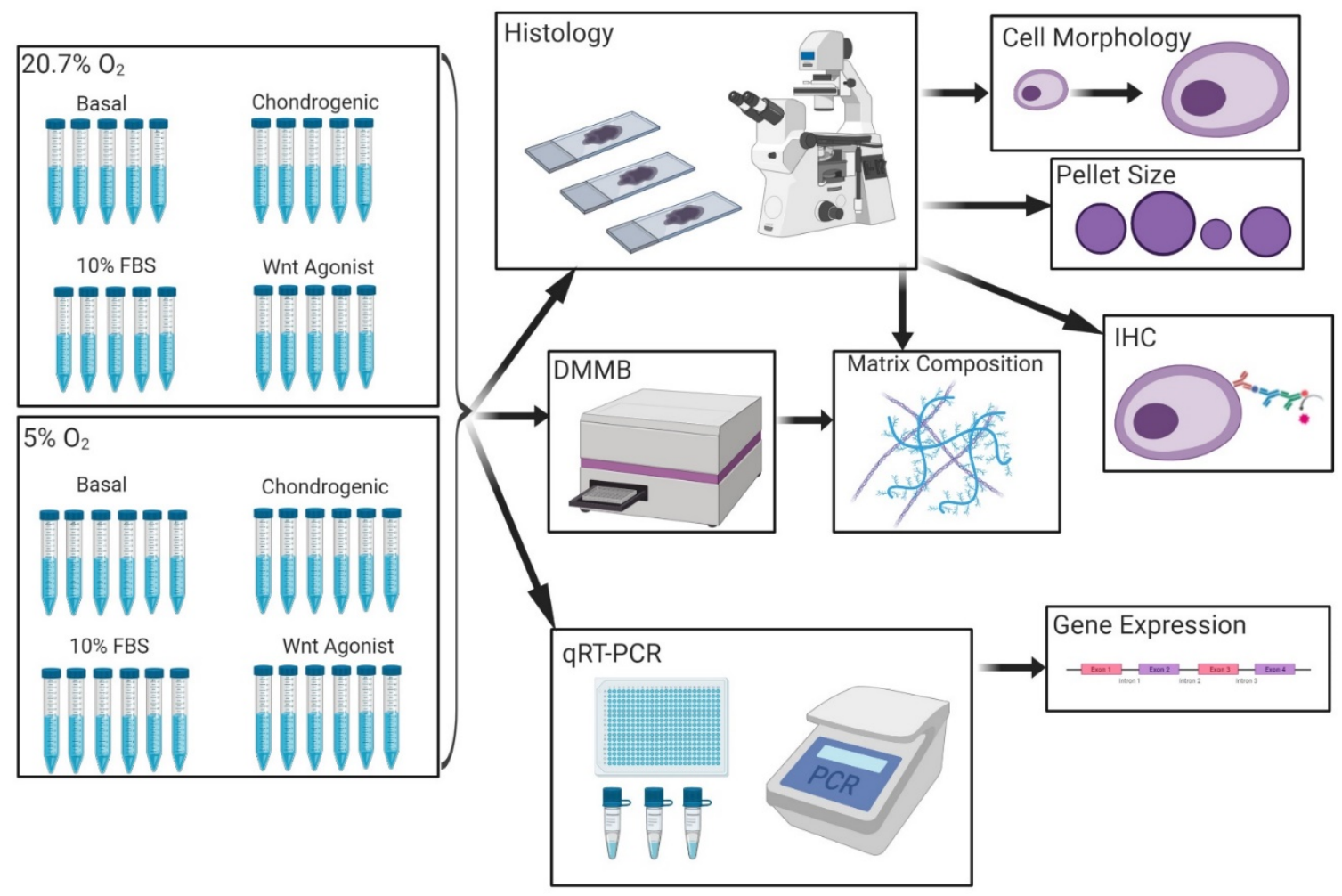




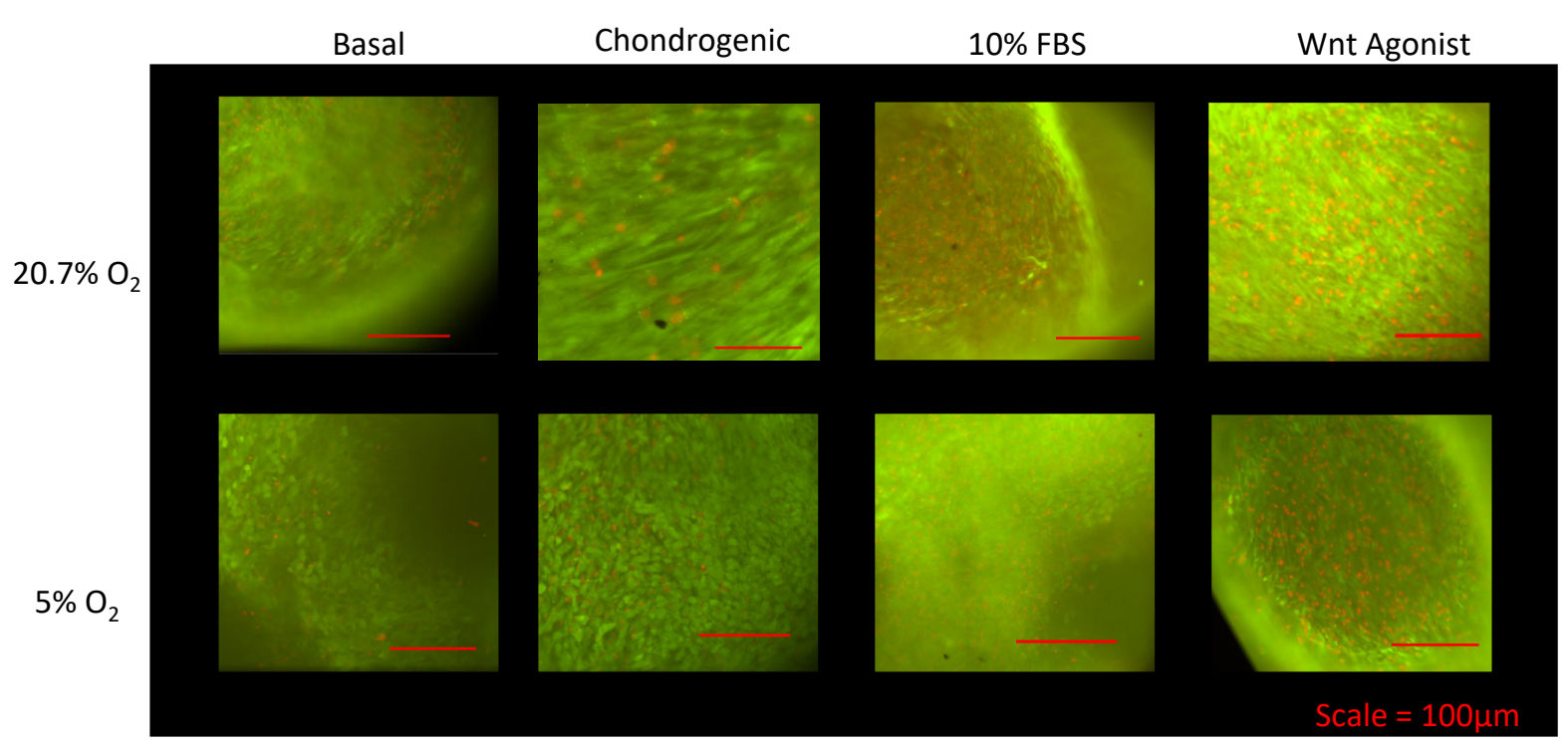

John Wiley \& Sons, Inc. 
a

Scale $=500 \mu \mathrm{m}$

$20.7 \% \mathrm{O}_{2}$

$5 \% \mathrm{O}_{2}$

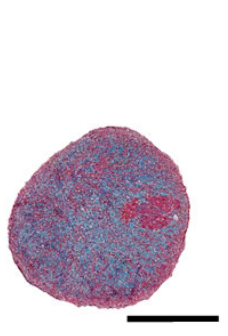

Basal

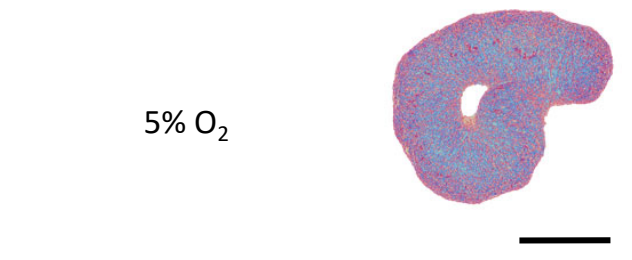

Chondrogenic
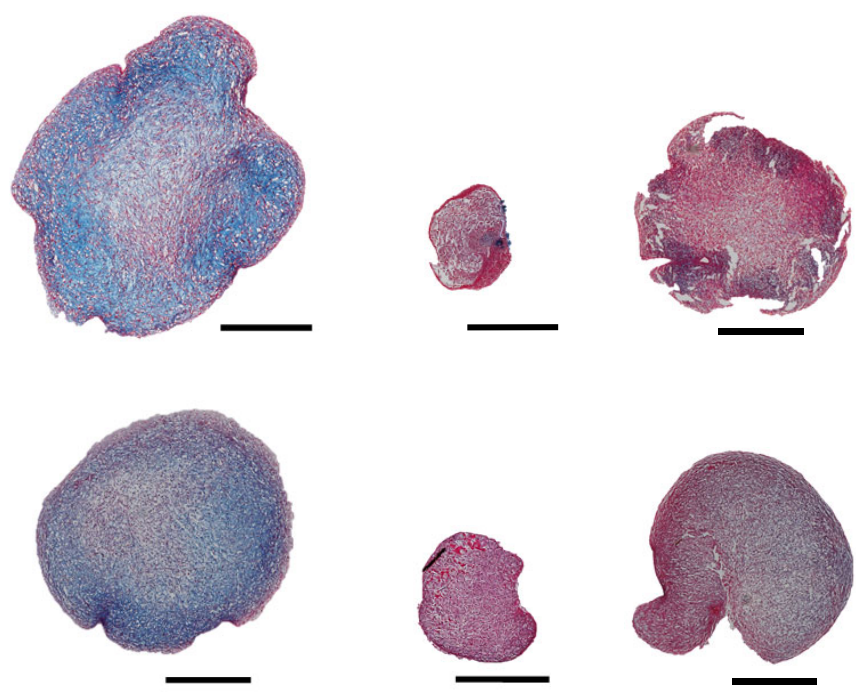

$10 \%$ FBS

Wnt Agonist
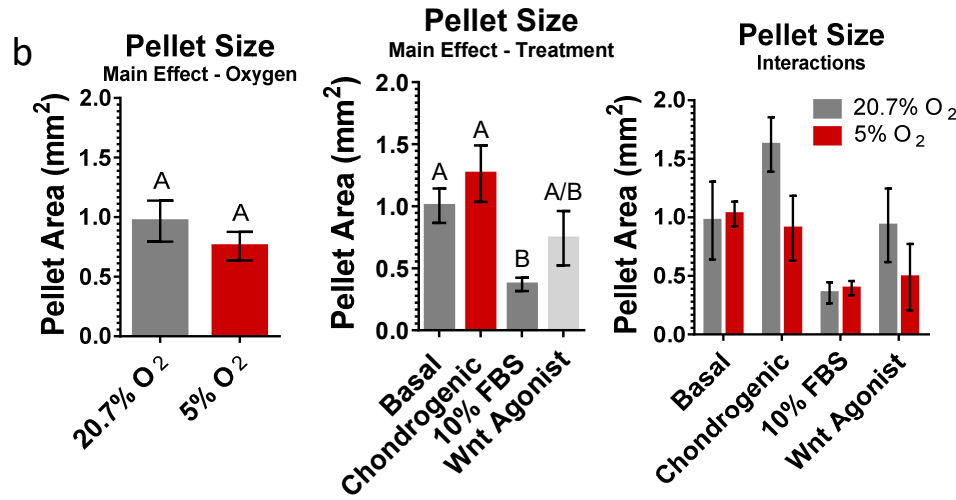

\begin{tabular}{|l|l|}
\hline $\begin{array}{l}\text { Main Effect } \\
\text { Oxygen }\end{array}$ & $p=0.218$ \\
\hline $\begin{array}{l}\text { Main Effect } \\
\text { Treatment }\end{array}$ & $p=0.011$ \\
\hline Interactions & $p=0.282$ \\
\hline
\end{tabular}




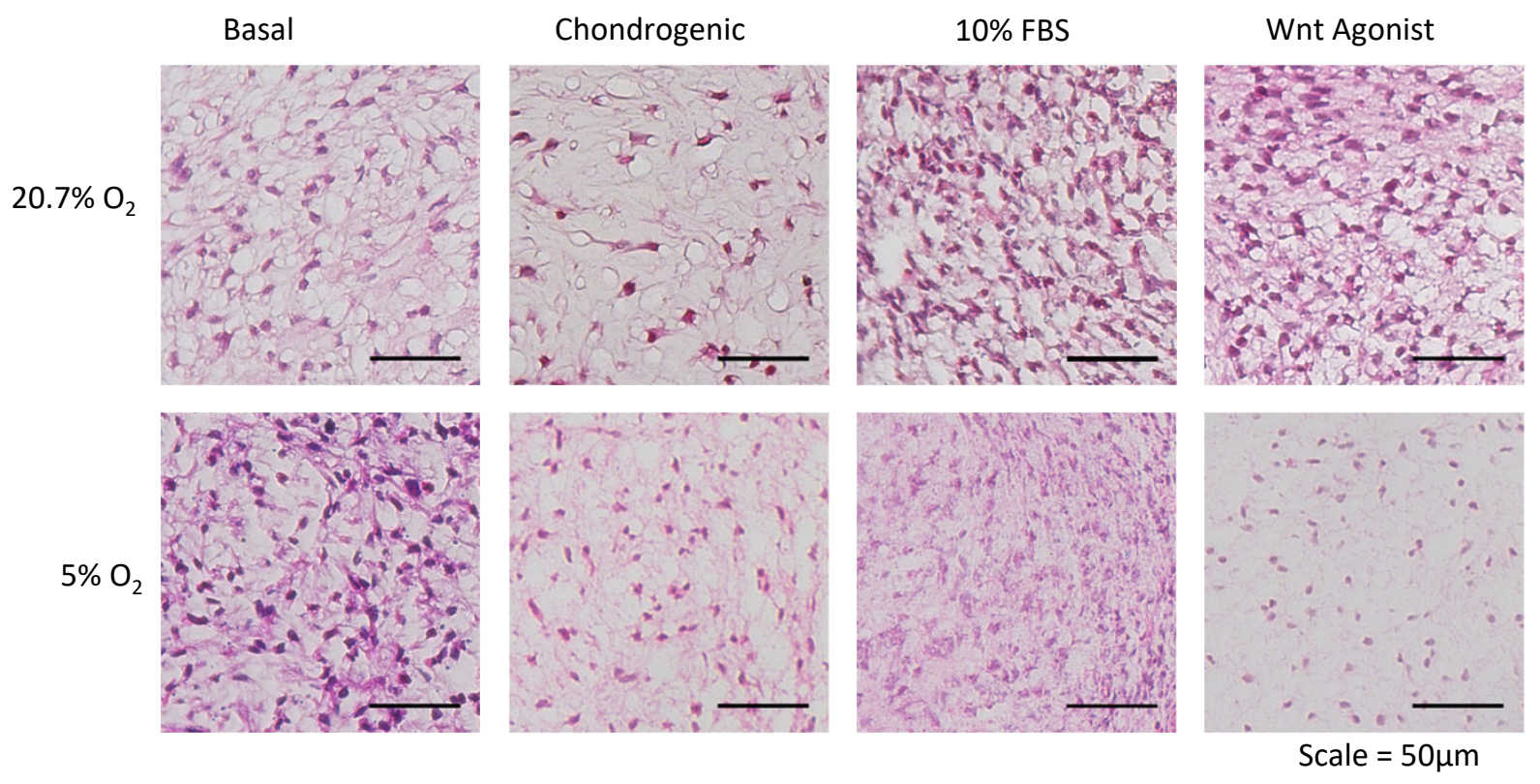

John Wiley \& Sons, Inc. 
a

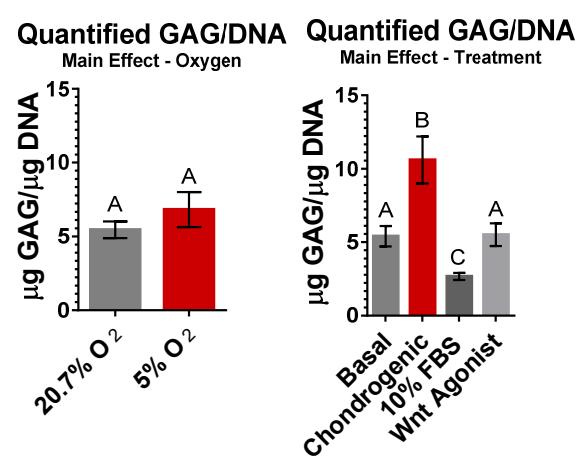

Quantified GAG/DNA

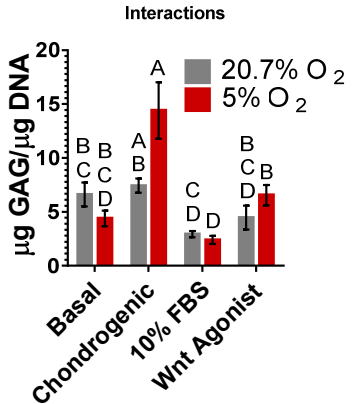

\begin{tabular}{|l|l|}
\hline $\begin{array}{l}\text { Main Effect } \\
\text { Oxygen }\end{array}$ & $p<0.001$ \\
\hline $\begin{array}{l}\text { Main Effect } \\
\text { Treatment }\end{array}$ & $p=0.371$ \\
\hline Interactions & $p=0.006$ \\
\hline
\end{tabular}

Quantified GAG

b Quantified GAG

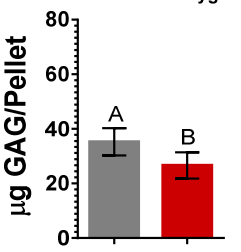

$200^{100}$
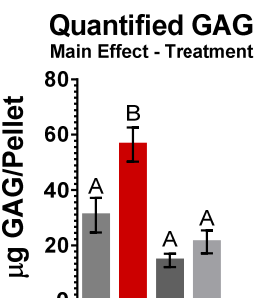

01

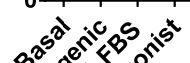

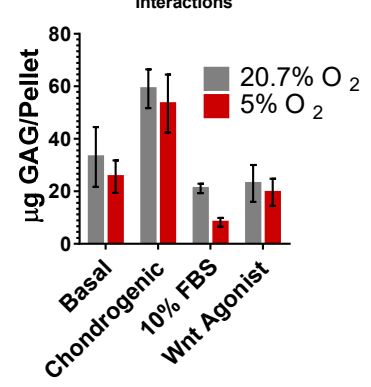

\begin{tabular}{|l|l|}
\hline $\begin{array}{l}\text { Main Effect } \\
\text { Oxygen }\end{array}$ & $p=0.043$ \\
\hline $\begin{array}{l}\text { Main Effect } \\
\text { Treatment }\end{array}$ & $p<0.001$ \\
\hline Interactions & $p=0.233$ \\
\hline
\end{tabular}
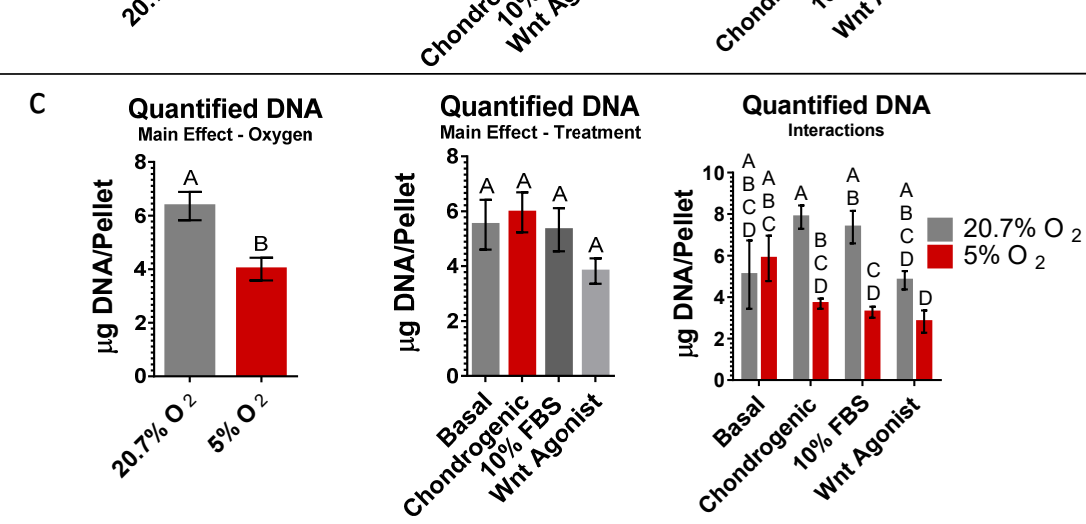

\begin{tabular}{|l|l|}
\hline $\begin{array}{l}\text { Main Effect } \\
\text { Oxygen }\end{array}$ & $p=0.072$ \\
\hline $\begin{array}{l}\text { Main Effect } \\
\text { Treatment }\end{array}$ & $p<0.001$ \\
\hline Interactions & $p=0.008$ \\
\hline
\end{tabular}


a $\quad 20.7 \% \mathrm{O}_{2}$

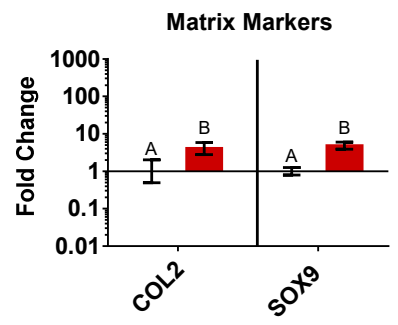

Hypertrophic Markers

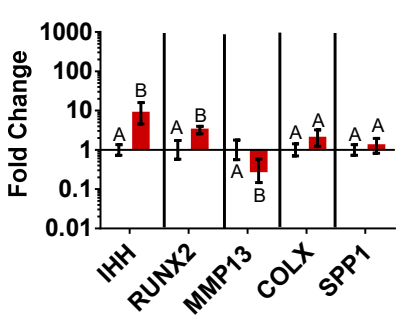

Neurovascular \& Inflammatory

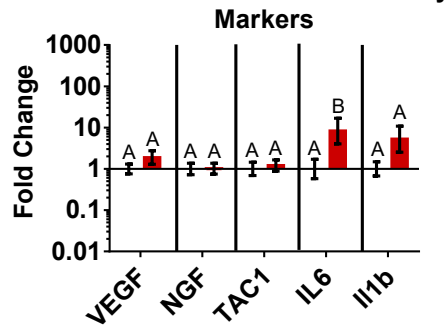

Basal

b

Chondrogenic
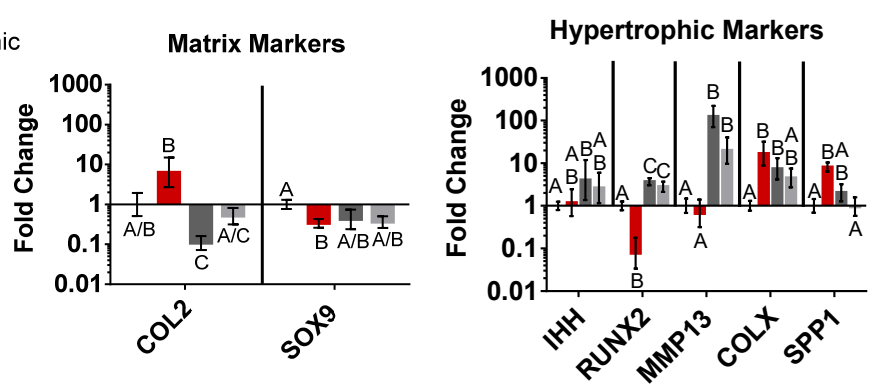

Neurovascular \& Inflammatory Markers

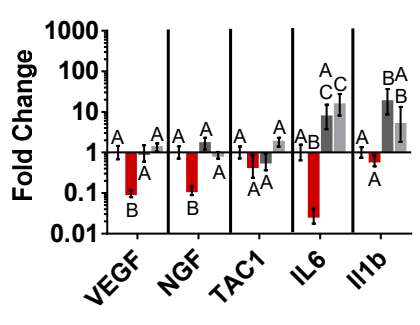

C $20.7 \% \mathrm{O}_{2}$

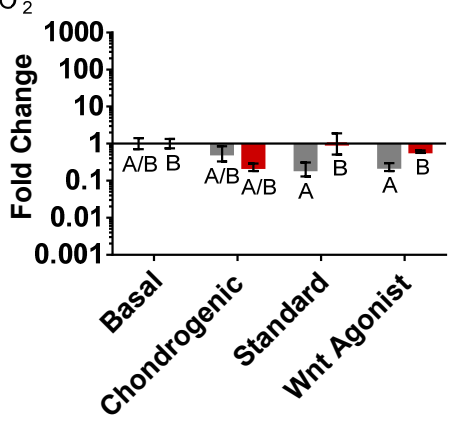

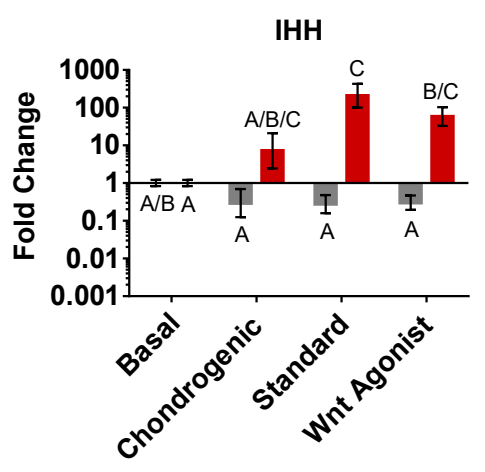

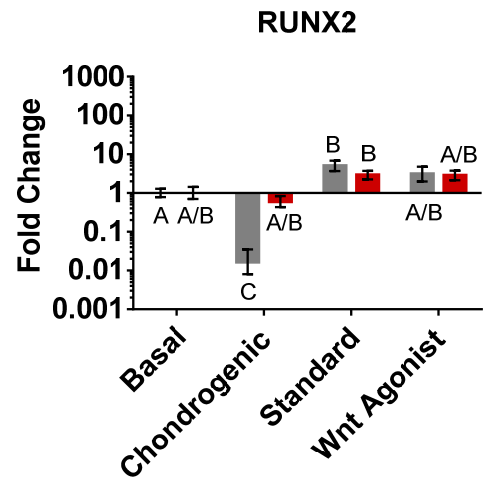

\begin{tabular}{|l|l|l|l|l|l|l|l|}
\hline Gene & $\begin{array}{l}\text { Main Effect } \\
\text { Oxygen }\end{array}$ & $\begin{array}{l}\text { Main Effect } \\
\text { Treatment }\end{array}$ & Interactions & Gene & $\begin{array}{l}\text { Main Effect } \\
\text { Oxygen }\end{array}$ & $\begin{array}{l}\text { Main Effect } \\
\text { Treatment }\end{array}$ & Interactions \\
\hline COL2 & $p=0.001$ & $p<0.001$ & $p=0.142$ & SPP1 & $p=0.611$ & $p=0.037$ & $p=0.611$ \\
\hline SOX9 & $p<0.001$ & $p=0.025$ & $p=0.015$ & VEGF & $p=0.072$ & $p<0.001$ & $p=0.098$ \\
\hline IHH & $p<0.001$ & $p=0.029$ & $p<0.001$ & NGF & $p<0.001$ & $p<0.001$ & $p=0.595$ \\
\hline RUNX2 & $p=0.003$ & $p<0.001$ & $p=0.027$ & TAC1 & $p=0.631$ & $p=0.095$ & $p=0.038$ \\
\hline MMP13 & $p=0.027$ & $p<0.001$ & $p=0.522$ & IL6 & $p<0.001$ & $p<0.001$ & $p=0.152$ \\
\hline COLX & $p=0.329$ & $p=0.004$ & $p=0.846$ & IL1b & $p=0.067$ & $p=0.007$ & $p=0.707$ \\
\hline
\end{tabular}



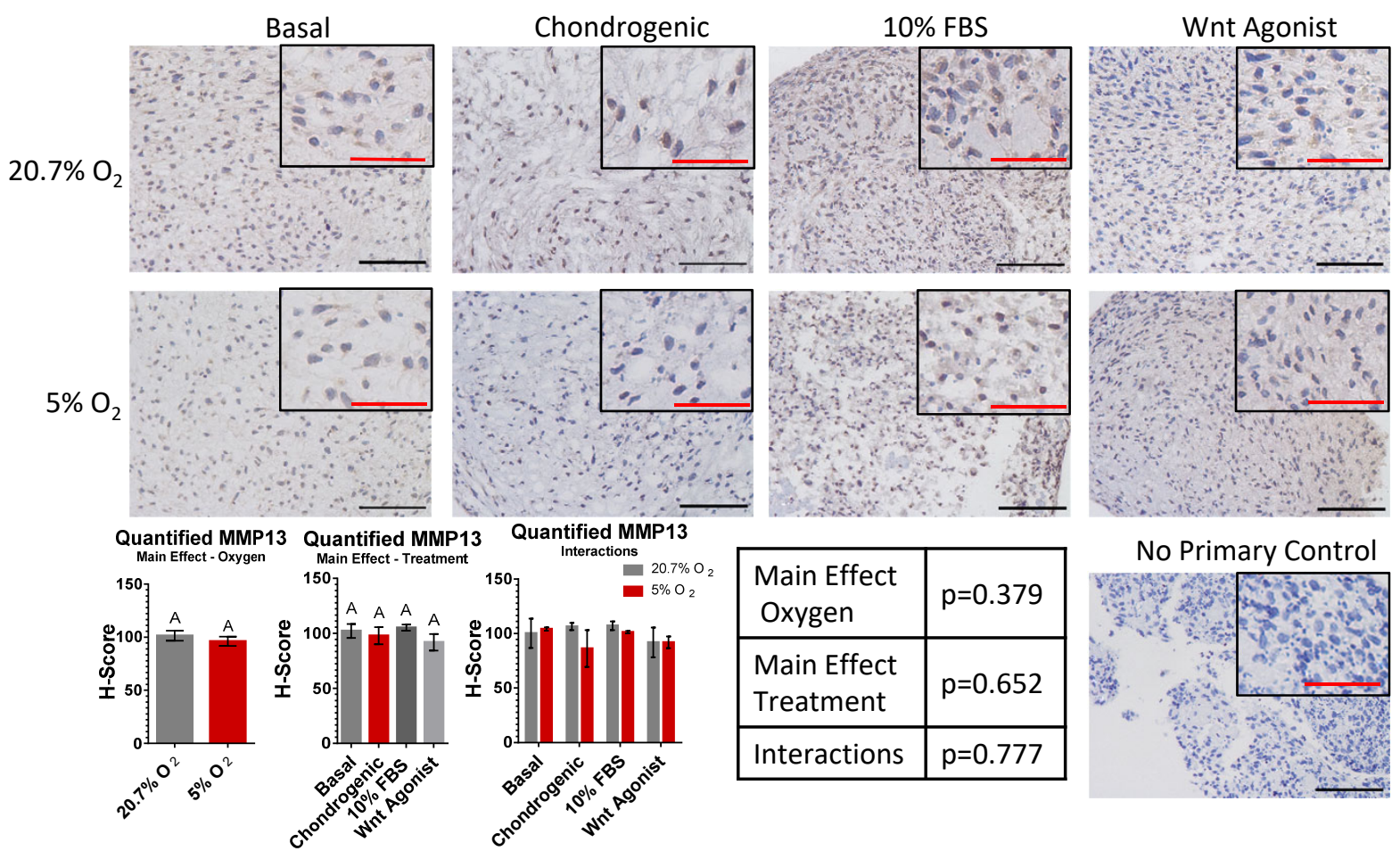

\begin{tabular}{|l|l|}
\hline $\begin{array}{l}\text { Main Effect } \\
\text { Oxygen }\end{array}$ & $p=0.379$ \\
\hline $\begin{array}{l}\text { Main Effect } \\
\text { Treatment }\end{array}$ & $p=0.652$ \\
\hline Interactions & $p=0.777$ \\
\hline
\end{tabular}

No Primary Control

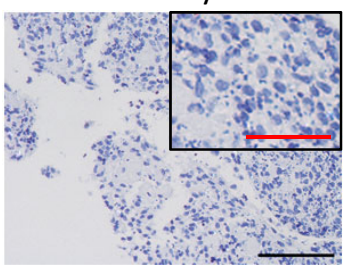




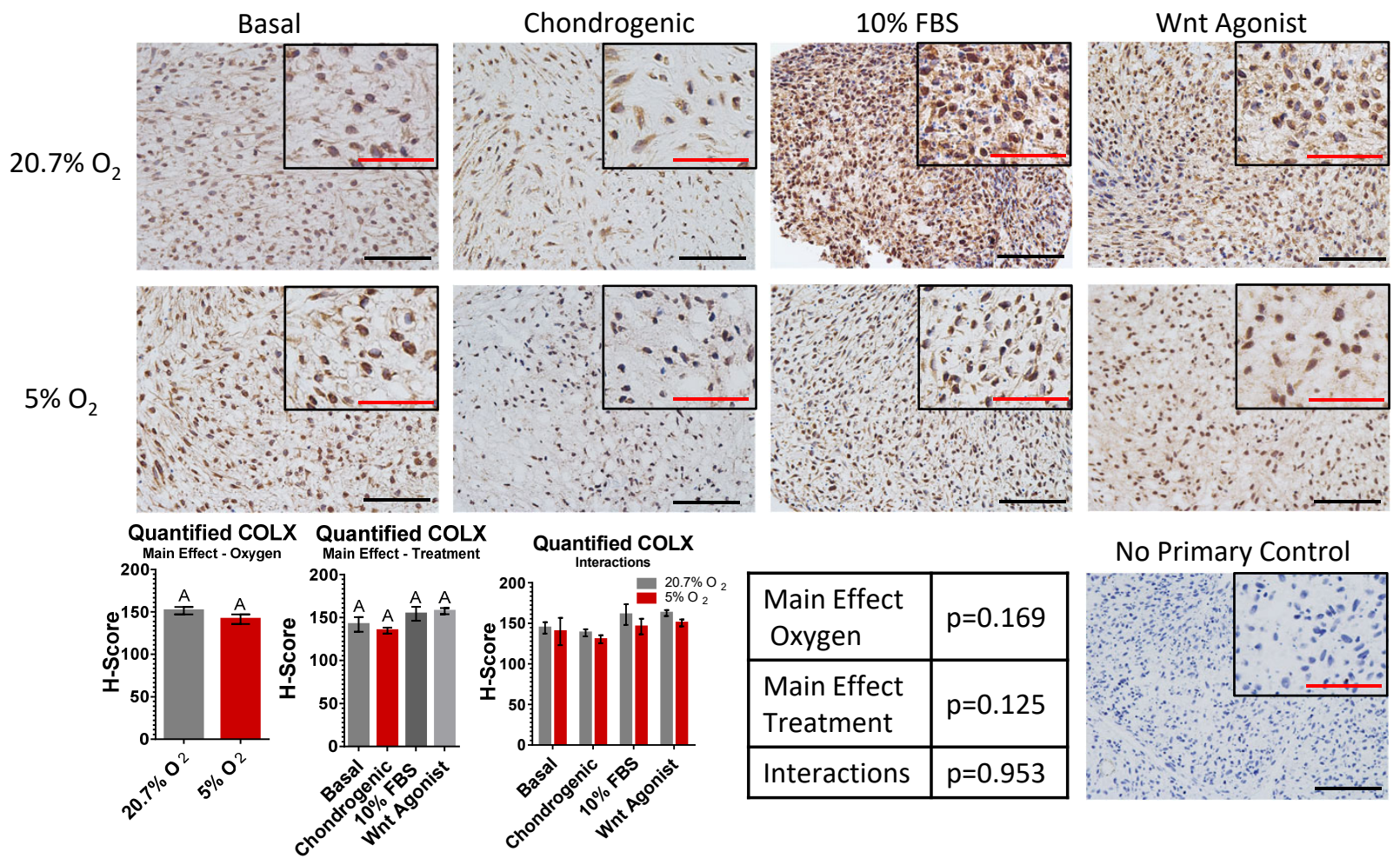


Table 1. Demographics for cadaveric specimens used and breakdown of study design, including which specimens were utilized in each group and overall sample sizes.

\begin{tabular}{|c|c|c|c|c|c|}
\hline ID & \multicolumn{2}{|l|}{ Sex } & Age & Level & $\begin{array}{l}\text { Thompson } \\
\text { Grade }\end{array}$ \\
\hline CEP1 & \multicolumn{2}{|c|}{ Female } & 43 & L1/L2 & 3 \\
\hline CEP2 & \multicolumn{2}{|c|}{ Female } & 49 & L3/L4 & $4-5$ \\
\hline CEP3 & \multicolumn{2}{|c|}{ Male } & 55 & L1/L2 & 3 \\
\hline CEP4 & \multicolumn{2}{|c|}{ Male } & 45 & L1/L2 \& L3/L4 & Both 3 \\
\hline CEP5 & \multicolumn{2}{|c|}{ Female } & 58 & L3/L4 \& L4/L5 & Both 2-3 \\
\hline CEP6 & \multicolumn{2}{|c|}{ Female } & 56 & L4/L5 & Unknown \\
\hline CEP7 & \multicolumn{2}{|c|}{ Male } & 46 & L3/L4 & $2-3$ \\
\hline CEP8 & \multicolumn{2}{|c|}{ Female } & 31 & L1/L2 & Unknown \\
\hline CEP9 & \multicolumn{2}{|c|}{ Female } & 30 & L2/L3 \& L4/L4 & Both 2-3 \\
\hline CEP10 & \multicolumn{2}{|c|}{ Female } & 59 & L3/L4 & 3 \\
\hline CEP11 & \multicolumn{2}{|c|}{ Female } & 19 & L3/L4 & 2 \\
\hline $\begin{array}{l}\text { Total } \\
n=11 \text { CEP }\end{array}$ & $\begin{array}{l}\text { Basal } \\
(n=7)\end{array}$ & $\begin{array}{l}\text { Chond } \\
(n=10)\end{array}$ & drogenic & $\begin{array}{l}10 \% \text { FBS } \\
(n=10)\end{array}$ & $\begin{array}{l}\text { Wnt } \\
\text { Agonist } \\
(n=10)\end{array}$ \\
\hline $\begin{array}{l}20.7 \% \mathrm{O}_{2} \\
(\mathrm{n}=5)\end{array}$ & $\begin{array}{l}\text { CEP4 } \\
\text { CEP7 } \\
\text { CEP9 } \\
\text { CEP10 } \\
\text { CEP11 }\end{array}$ & $\begin{array}{l}\text { CEP4 } \\
\text { CEP7 } \\
\text { CEP9 } \\
\text { CEP10 } \\
\text { CEP11 }\end{array}$ & & $\begin{array}{l}\text { CEP4 } \\
\text { CEP7 } \\
\text { CEP9 } \\
\text { CEP10 } \\
\text { CEP11 }\end{array}$ & $\begin{array}{l}\text { CEP4 } \\
\text { CEP7 } \\
\text { CEP9 } \\
\text { CEP10 } \\
\text { CEP11 }\end{array}$ \\
\hline $\begin{array}{l}5 \% \mathrm{O}_{2} \\
(\mathrm{n}=10)\end{array}$ & $\begin{array}{l}\text { CEP2 } \\
\text { CEP4 } \\
\text { CEP7 } \\
\text { CEP8 } \\
\text { CEP9 } \\
\text { CEP10 }\end{array}$ & $\begin{array}{l}\text { CEP1 } \\
\text { CEP2 } \\
\text { CEP3 } \\
\text { CEP4 } \\
\text { CEP5 } \\
\text { CEP6 }\end{array}$ & & $\begin{array}{l}\text { CEP1 } \\
\text { CEP2 } \\
\text { CEP3 } \\
\text { CEP4 } \\
\text { CEP5 } \\
\text { CEP6 }\end{array}$ & $\begin{array}{l}\text { CEP1 } \\
\text { CEP2 } \\
\text { CEP3 } \\
\text { CEP4 } \\
\text { CEP5 } \\
\text { CEP6 }\end{array}$ \\
\hline
\end{tabular}


Table 2. Genes and corresponding description of genes evaluated using qRT-PCR.

\begin{tabular}{|c|c|}
\hline Target gene & Role \\
\hline $\begin{array}{l}18 \mathrm{~s} \\
4333760 \mathrm{~F}\end{array}$ & Housekeeping gene \\
\hline $\begin{array}{l}\text { COL2A1 } \\
\text { Hs00264051_m1 }\end{array}$ & $\begin{array}{l}\text { Matrix marker; indicates } \\
\text { chondrogenic phenotype }\end{array}$ \\
\hline $\begin{array}{l}\text { SOX9 } \\
\text { Hs00165814_m1 }\end{array}$ & $\begin{array}{l}\text { Matrix marker; indicates } \\
\text { chondrogenic phenotype }\end{array}$ \\
\hline $\begin{array}{l}\text { IHH } \\
\text { Hs00745531_s1 }\end{array}$ & Hypertrophic marker \\
\hline $\begin{array}{l}\text { RUNX2 } \\
\text { Hs01047973_m1 }\end{array}$ & Hypertrophic marker \\
\hline $\begin{array}{l}\text { MMP13 } \\
\text { Hs00233992_m1 }\end{array}$ & $\begin{array}{c}\text { Matrix degrading } \\
\text { enzyme; indicates } \\
\text { hypertrophic phenotype }\end{array}$ \\
\hline COL10 & Hypertrophic marker \\
\hline SPP1 & Hypertrophic marker \\
\hline $\begin{array}{l}\text { VEGFA } \\
\text { Hs00900055_m1 }\end{array}$ & Angiogenic marker \\
\hline $\begin{array}{l}\text { NGF } \\
\text { Hs00171458_m1 }\end{array}$ & Neurogenic marker \\
\hline $\begin{array}{l}\text { TAC1 } \\
\text { Hs00243225_m1 }\end{array}$ & $\begin{array}{l}\text { Substance } P \text {; indicates } \\
\text { pain }\end{array}$ \\
\hline $\begin{array}{l}\text { IL6 } \\
\text { Hs00174131_m1 }\end{array}$ & Inflammatory marker \\
\hline $\begin{array}{l}\text { IL1 } \beta \\
\text { Hs00174097_m1 }\end{array}$ & Inflammatory marker \\
\hline
\end{tabular}

